\title{
Albanian Diaspora in Greece in the years 1990-2000
}

\author{
Msc. Mustafa Kadzadej \\ mustafakadzadej@ymail.com \\ Msc. Kleviona Hoxha \\ klevianahoxha@ymail.com
}

\begin{abstract}
s
The reasons that prompted the Albanian exodus were numerous and varied. While if we take a look on its consequences will see that they have a dual nature. Among the positive aspects of exodus we can mention the fact that it helped Albania economically meeting the needs of a considerable part of the population in the moment of political and social crisis transition enabling the survival of many families. ${ }^{1} \mathrm{On}$ the other hand it had a negative impact not only becouse of spending vital energies of the nation abroad, but also because it led to the formation of a bad opinion about Albanians, opinion spread almost all over Europe, especially where their presence was bigger. ${ }^{2}$ For this reason we got to study precisely the image of immigrant in two countries ( Italy and Greece ), where they have the largest flow of migration in 1990-2000. We should note that in recent years in both countryes in Italy and in Greece prevails the same closed mentality against foreigners. Also it is accompanied ( especially in Italy with the malfunctioning of the structure that handles issues of migratory movements, not like in the other states like Germany, England or France where, besides the small number of immigrants, there were laws and better functioning of the state that associated with emigration's problems. On the other hand we can say that in this period, whether in Greece the fortunes of the Albanian immigrants depended from the relations of the GreekAlbanian state, in Italy they depend mainly on the behavior of immigrants. ${ }^{3}$

" Invasion " of embassies, mass departures at the border, and the exodus in general, following the collapse of Albania 's totalitarian regime in the early 90 's, and marked the origin of the formation of the Albanian Diaspora. According to the researchers R. Devole compactness of the concept of " Albanian diaspora ", depends of homogenising effect means of mass proclamation, which as a consequence of technological developments of recent years, they can provide culturally emigrants everywhere. ${ }^{4}$
\end{abstract}

Albanian immigrants in Greece constitute a community with different characteristics from their compatriots residing in the Unitet State of America. The differences are largely determined by relations with host countries, but also from the body, identity processes, distance from the birthplace, etc. From this perspective, the Albanian diaspora is better to be used in the plural than in the singular. ${ }^{5}$ When the ships of Albanian exodus set sail to the coast, in Europe was waiting cameras and cameras of the whole world. Solidity of negative images of Albanians depends on the raw materials used for its manufacture : news, television footage, photographs, films, articles, interviews, analysis, documentaries, reportages, sounding titles, chronicles, etc. From this media curfew in few causes can be "good albanians". ${ }^{6}$

Fluent Italian, wearing fashionable, European faces, dignified culture, fell necessarily in conflict with the image of barbarity imparted by the media, but not to the extent as to bring in crisis the bredore coherence of the negative myth of Albanians. ${ }^{7}$ The following years this myth on the Albanians would start to fade gradually, but without losing its shape. That's because this period coincided with the television success of several Albanian artists, who with their ingenuity showed the opposite about the negative image of the Albanian community. If smaller and criminal event which will be included any Albanian

\footnotetext{
${ }^{1}$ Fabian Kurti. "About the Albanian Emmigration", Përpjekja, Nr. 9-12 1997. 14

2 The same,

3 The same, 15

${ }^{4}$ Rondo Devole, Bridge over sea, (Tirane: Ora 2008) , 160

5 Devole,Bridge..., 161

${ }^{6}$ Rondo Devole. "Albanians in Italy" Përpjekja, Nr.26-27 2010, 96

${ }^{7}$ Devole, Bridge over..., 185
} 
would myth reborn with all its strength, bringing a political instrumentalisation of the events. In addition, for the first time in Albanian immigration history in Italy was verified harmful racizm acts to their detriments. ${ }^{1}$ However, there is no denying that Albanian emigrants are already an integral part of Italian society. Perhaps it is no exaggeration to say that Albanians are one of inclined groups to be integrated, as is obvious from different data like: presence in the labor market, the percentage of family with permanent residence, level of education, high school attendance, and the cultural approach and attitude. ${ }^{2}$ This influenced perhaps because in Italy we will have a significant presence of intellectuals and cultural elite of the country, who after 90 years chose to continue their activity abroad.

Although according the data the majority of them will migrate mainly in the US and in other countries in Western Europe. ${ }^{3}$ Meanwhile, regarding the situation of Albanians in Greece in the years 1990-2000, we can not say that we have sufficient resources to present a comprehensive situation associated with their image in the media and the Greek press,but present to us the study of R. King and J. Vullnetari can say that it was similar to the Italian in many aspects. After the first welcoming, the image of Albanians was disintegrated by some stereotypes, which should be noted that constituted a small minority.

But a major impact would have the historical past of the two countries after the breakup of the Ottoman Empire, which would penalize in many aspects Albanian immigrants in Greece. During this period another aspect that would bring prejudice to the Albanian community,would be the differentiation of the state and the Greek society will do among the " half etnic Greek Albanian's " ( mainly from areas of southern Albania ) and " other Albanian ", which would bring differences in their rights. ${ }^{4}$

The Common of both countries is that Albanian emigration, despite stereotypes used by the media to characterize it, has achieved a high degree of integration in the socio- economic life of these countries. ${ }^{5}$

About the cultural integration of Albanian emigrants in the countries where they have settled over the years 1990-2000, we can not say that in all the places he has been uneven. By the sources used by us, although in small numbers, we can see that this process is not developed with the same intensity in all countries where Albanians have emigrated. This can be explained by several reasons, among which the most important would be ; the size and compactness of the Albanian community, and in the other side the tendency of the recipient companies to allow the organization of immigrants on the basis of ethnicity, coupled with a high degree of tolerance. But on the other side the Albanian emigration can distinguish different trend. In neighboring countries such as Italy and Greece where is the concentrated and the largest number of immigrants, during the whole period of the 90 's Albanians have a few cultural activitie, because of prejudices that hinder the integration in economic life.

As in other western countries like the US, France, Germany, England, Sweden, Switzerland, etc., the cultural organization and the integration in the local society without losing national identity was bigger. Albanians were integrated in the social life of the country by participating in associations of migrants in cooperation with the citizens and institutions of the host country. Most associations were created in 1998. A primary concern has been to preserve the associations of Albanian identity, against prejudice and racism.

Suggested by Barjaba and King about the Greece and Italy, organized in association between Albanians has been weak. primarily because of the marginality of their economic and legal status, but also because of the antipathy of their commitment to community organizations to, that remind the communist past. ${ }^{6}$ This makes that their cultural activity was not well documented. One of the resources used to reflect the cultural activity of Albanian emigrants are mainly periodicals, newspapers and magazines, through which we tried to get reliable data. But as to their number, as well as often little material they contain, it can not be said that we have failed to reflect the extent necessary, and at all stages that follow this activity. However relying on these sources can make generalizations and cultural activities of Albanian immigrants, certainly in some countries maintaining its specificity. A magazine that reflection the great diaspora activity, whether it be early and

\footnotetext{
1 Devole. "Albanians in Italy", 97

2 Devole. "Albanians in Italy", 99

${ }^{3}$ Russell King and Julie Vullnetari, Migration and Development in Albania, Sussex Centre for Migration Reserch, December 2010,36

${ }^{4}$ King and Vullnetari, Migration and Development in Albania, 38

5 The same, 32

${ }^{6}$ Niko Gogonas. "Language of second generation immigrants in Greece", Përpjekja, Nr.26-27, 2010, 108 
that of after 90 years, has been " the Albanian Diaspora ". This magazine, " claims to be a forum of Diaspora figures, problems, messages, voices coming from far away, wherever the compatriots are found. In the first issue of it claims that " will be linked to the current, culture, historical tradition, and in it will be reflected the Albanian emmigration issues, activities of associations operating in the Diaspora, diaspora's figures of our days etc. ${ }^{1}$

In the pages of this magazine, we will find reflected part of the life of countries where immigrants live.

Regarding the Albanian cultural activity of Australia, we learn that there is an organized community of Albanian man in Melbourne has just 6 Albanian schools, which teach Albanian girls and boys. On behalf of the Albanian issue are two centers, Muslim and Catholic, raised by the Albanians. ${ }^{2}$ It is impressive the existence of an Albanian-language radio station in Malburn, directed by Hikmet Ndreu. ${ }^{3}$ However it is unclear whether this community is formed mainly by immigrants come after 90 years, or it is attached to the old diaspora that existed there.

\footnotetext{
1 Magazine "Albanian Diaspora", Tirane, nr.1, september 1998, 2

2 The same, 38

3 The same, 39
} 